\title{
Screening of Different Extracts of Marine Macro Green Algae for Larvicidal Activity against Dengue Fever Mosquito, Aedes aegypti (Diptera: Culiadae)
}

\section{G. Adaikala Raj ${ }^{1}$, M. Jayaraman ${ }^{1}$, S. Krishnamoorthy ${ }^{1}$, M. Chandrasekaran ${ }^{1 *}$ and V. Venkatesalu ${ }^{1}$}

${ }^{1}$ Department of Botany, Annamalai University, Annamalainagar - 608 002, Tamil Nadu, India

*chandruphd@yahoo.co.in (M. Chandrasekaran)

\section{Keywords: Marine macro green algae, Aedes aegypti, Phytochemical analysis}

\begin{abstract}
The present study larvicidal activities of hexane, chloroform, ethyl acetate, acetone and methanol extracts of Halimeda macroloba, Decsne, Caulerpa racemosa (Frosk) Weber-Van-Bosses and Ulva lactuca Lin, (Chlorophyceae) against Aedes aegypti. The marine macro green algae extracts were tested against early $4^{\text {th }}$ instar larvae of $A$. aegypti using WHO protocol and concentrations of 200, 400,600,800 and $1000 \mathrm{ppm}$. The observed mortality was made 24 and $48 \mathrm{~h}$ after treatment, data was subjected to probit analysis to determine the lethal concentration $\left(\mathrm{LC}_{50}\right.$ and $\mathrm{LC}_{90}$ ) of the treated larvae of the tested species. Among the tested extracts the maximum efficacy was observed in the ethyl acetate extracts. The ethyl acetate extracts of the seaweeds showed the presence of terpenoids, tannins and phenolic compounds stronger than the other extracts. The results revealed that all the extracts showed varied levels of larvicidal activity against $A$. aegypti tested. However, the ethyl acetate extract of C. racemosa showed remarkable larvicidal activity against $A$. aegypti $\left(\mathrm{LC}_{50}=579.9\right.$ and $\mathrm{LC}_{90}=1255.4 \mathrm{ppm}$ values at $24 \mathrm{~h}$ and $\mathrm{LC}_{50}=495.4$ and $\mathrm{LC}_{90}$ $=1073.9 \mathrm{ppm}$ at $48 \mathrm{~h})$ followed by $U$. lactuca $\left(\mathrm{LC}_{50}=588.1\right.$ and $\mathrm{LC}_{90}=1290.7 \mathrm{ppm}$ values at $24 \mathrm{~h}$, and $\mathrm{LC}_{50}=530.8$, and $\mathrm{LC}_{90}=1160.0 \mathrm{ppm}$ at $48 \mathrm{~h}$ ), respectively. The lowest larval mortality was observed with hexane extract of $H$. macroloba against $A$. aegypti with values of $\mathrm{LC}_{50}=1116.8$ and $\mathrm{LC}_{90}=1824.5 \mathrm{ppm}$ (after $24 \mathrm{~h}$ ) and $\mathrm{LC}_{50}=1059.9$ and $\mathrm{LC}_{90}=1768.3 \mathrm{ppm}$ (after $24 \mathrm{~h}$ ). The present studies indicate that the larvicidal activity and phytochemicals derived from the ethyl acetate extract of $C$. racemosa have the potential to be used as an ideal eco-friendly approach and effective mosquito vector control agent.
\end{abstract}

\section{Introduction}

Marine algae are one of the most important producers of biomass in the marine environment. They produce a wide variety of chemically active metabolites in their surroundings to protect themselves against other settling organisms [1]. So far, it was evidenced that marine algae are potential antimutagenic, anticoagulant and antitumor agent. Up to now, numerous studies have confirmed the anti-HSV activity of algae that increase the interest in algae as a source of antiviral compounds. Marine macro algae are an excellent source of vitamins such as A, B1, B12, C, D, E, riboflavin, niacin, pantothanic acid and folic acid as well as minerals such as $\mathrm{Ca}, \mathrm{P}, \mathrm{Na}$ and $\mathrm{K}$ [2]. Chlorophyceae seaweeds, popularly known as green algae, are widely distributed in both inter-tidal and deep-water regions of the seas. More recent reports indicate that in many parts of the world marine algae are still used in folk medicine for the treatment of a variety of disease [3].

Vector-borne diseases are dengue, malaria, filariasis, dengue haemorrhagic fever schistosomiasis, leishmaniasis, chagas disease, yellow fever, lymphatic filariasis, African trypanosomiasis and onchocerciasis [4]. Aedes aegypti (Culicidae) occurs in Asia, Africa, Central and South America and transmits virus of Flavi virus genus, etiologic agents of human diseases like dengue and yellow fever [5]. On the other hand, there is no vaccine for dengue fever; vector control is the only method used to minimize the transmission of the virus. Dengue fever can be caused by four serotypes of the dengue arbovirus and clinically can happen in asymptomatic forms, classic dengue fever, hemorrhagic dengue fever and other more severe forms. Worldwide, 2.5 billion of 
people are in risk to acquire the disease and 50 million are infected every year, characterizing a pandemia [6].

Plant extracts and phytochemicals have potential as mosquito control agents because many of them are selective, may biodegrade to nontoxic products and may be applied to mosquito breeding sites in the same way as conventional insecticides [7]. Each year, an increasing number of novel marine metabolites are reported in the literature, indicating that the marine environments is likely to continue to be a prolific sources of more natural products for many years to come. Several studies have demonstrated that marine algae have biological activity such as larvicidal, antifeedant and anticoagulant [8].

Therefore, the present study was carried out to evaluate the larvicidal properties of marine macro green algae of different extracts against the dengue fever mosquito, A. aegypti.

\section{Materials and Methods}

\subsection{Plants sample collection}

Halimeda macroloba, Decsne and Caulerpa racemosa (Frosk.) Weber-Van-Bosses were collected from various places in Mandapam (Lat. 09 $17.417^{\prime} \mathrm{N}$; Long. $079^{\circ} 08.558^{\prime} \mathrm{E}$ ) at Rameshwaram district, Ulva lactuca Lin (Chlorophyceae) were collected from various places in Manappad (Lat. 09 $17.417^{\prime} \mathrm{N}$; longitude $079^{\circ} 08.558^{\prime} \mathrm{E}$ ), at Tuticorin district, Gulf of Mannar marine Biosphere Reserve, Tamilnadu, India. The collections were made during the months of November and December 2012. The algae were identified by Dr. R. Selvaraj, Former Professor, Department of Botany, Annamalai University and the museum specimens are deposited in the Department of Botany, Annamalai University, Annamalai Nagar, Tamil Nadu, India.

\subsection{Preparation of extracts}

Algal species were handpicked from rocks and shells submerged under water during low tide. They were washed thoroughly with sea water to remove all unwanted impurities, epiphytes, animal casting and adhering sand particles etc., Morphologically distinct thallus of algae were placed separately in new polythene bags and were kept in an ice box containing slush ice and transported to the laboratory. Then, the samples were blot dried using sterile tissue paper. The seaweed materials dried in one week in room temperature. After getting from all the samples were grounds in to a fine powder. Five hundred grams of finely ground algal powder material were packed in Whatman filter paper. The powdered samples were extracted with different organic solvents in a Soxhlet apparatus for 72 hours with increasing polarity viz., hexane, chloroform, ethyl acetate, acetone and methanol. The extracts were concentrated to solvents free by evaporation in a rotary vacuum evaporator (Heidolph, Germany) at a temperature less than $40{ }^{\circ} \mathrm{C}$. The crude extracts were obtained were kept at $4{ }^{\circ} \mathrm{C}$ for larvicidal assay.

\subsection{Phytochemical screening}

The qualitative phytochemical analyses of hexane, chloroform, ethyl acetate, acetone and methanol extracts of $H$. macroloba, C. racemosa and U. lactuca (Chlorophyceae). Phytochemicals like terpenoids, tannins, cardic glycosides, steroids, alkaloids, phenolic compounds and coumarins were carried out according to the method [9].

\subsection{Mosquito larvicidal assay}

The eggs of A. aegypti were received from the Field Station, Centre for Research in Medical Entomology (ICMR-Government of India), Viruthachalam. The egg rafts of A. aegypti were kept in the tray containing tap water (culture medium) at a laboratory condition $\left(29 \pm 3{ }^{\circ} \mathrm{C}, 75\right.$ to $85 \% \mathrm{RH}$, 14:10 light and dark photo period). After $24 \mathrm{~h}$ of incubation, the eggs were observed for hatch out in to first instar larvae. Appropriate amount of nutrient (sterilized fed with Brewer's yeast/ dog biscuit 1:3 ratio). The $4^{\text {th }}$ instar larvae were used in the study.

The larvicidal activity was observed as per the standard procedures recommended [10]. The seaweeds extracts were dissolved in $2 \mathrm{ml}$ dimethyl sulfoxide (DMSO) and prepared into different 
concentrations viz., 200, 400, 600, 800 and $1000 \mathrm{ppm}$ were prepared with distilled water. Twenty larvae (in a $100 \mathrm{ml}$ beaker) of early fourth instar stage were used for larvicidal assay and five replicates were maintained for each concentration. During this experiment, no food was offered to the larvae. The larval mortality was calculated after 24 and 48 hours of the exposure period. All moribund mosquito larvae were considered as dead. The larval mortality was also checked for water and DMSO individually.

\subsection{Statistical Analysis}

The results are expressed as the mean \pm SD. All statistical analyses were performed using SPSS version 16.0 statistical software (SPSS Inc., Chicago, IL, USA). The average larval mortality data were subjected to probit analysis calculating $\mathrm{LC}_{50}, \mathrm{LC}_{90}$ and other statistics, $95 \%$ confidence limits and chi-square values were calculated.

\section{Results and Discussion}

\subsection{Phytochemical analysis}

The hexane, chloroform, ethyl acetate, acetone and methanol extracts were analyzed for phytochemicals, terpenoids, tannins, cardiac glycosides, steroids, alkaloids, phenolic compounds and coumarins (Table 1). The ethyl acetate extracts of H. macroloba, C. racemosa and $U$. lactuca showed the presence of phytochemicals, terpenoids, tannins and phenolic compounds strongly than the other extracts. Among the phytochemicals, cardiac glycosides were present in all the extracts except acetone and methanol. Steroids were present in all the extracts of $C$. racemosa, H. macroloba and U. lactuca expect actone and methanol extracts of H. macroloba. Alkaloids and coumarins were absent in all the extracts of H. macroloba, C. racemosa and U. lactuca.

Table 1. Phytochemical constituents of marine macro green algae extracts.

\begin{tabular}{|c|c|c|c|c|c|c|c|}
\hline \multirow{2}{*}{$\begin{array}{c}\text { Seaweed } \\
\text { extracts } \\
\text { prepared with } \\
\text { different } \\
\text { solvents }\end{array}$} & \multicolumn{7}{|c|}{ Secondary metabolites } \\
\hline & Terpenoids & Tannins & $\begin{array}{c}\text { Cardic } \\
\text { glycosides }\end{array}$ & Steroids & Alkaloids & $\begin{array}{c}\text { Phenolic } \\
\text { compounds }\end{array}$ & Coumarins \\
\hline \multicolumn{8}{|c|}{ Halimeda macroloba } \\
\hline Hexane & + & - & + & + & - & + & - \\
\hline Chloroform & + & - & - & + & - & ++ & - \\
\hline Ethyl acetate & ++ & ++ & + & + & - & +++ & - \\
\hline Acetone & - & + & - & - & - & + & - \\
\hline Methanol & - & + & - & - & - & + & - \\
\hline \multicolumn{8}{|c|}{ Caulerpa racemosa } \\
\hline Hexane & ++ & - & + & + & - & + & - \\
\hline Chloroform & +++ & - & - & ++ & - & ++ & - \\
\hline Ethyl acetate & +++ & +++ & + & ++ & - & +++ & - \\
\hline Acetone & - & + & - & + & - & + & - \\
\hline Methanol & - & + & - & + & - & + & - \\
\hline \multicolumn{8}{|l|}{ Ulva lactuca } \\
\hline Hexane & ++ & - & + & + & - & + & - \\
\hline Chloroform & ++ & + & - & + & - & ++ & - \\
\hline Ethyl acetate & ++ & +++ & + & ++ & - & +++ & - \\
\hline Acetone & - & + & - & + & - & + & - \\
\hline Methanol & - & + & - & + & - & + & - \\
\hline
\end{tabular}

$-=$ Absence,$+=$ weak,$++=$ medium,$+++=$ strong 


\subsection{Larvicidal activity}

Current strategies based on the elimination of breeding sites and applications of chemical insecticides for larval and adult mosquito control have resulted in development of resistance without eliminating the constant risk of dengue epidemics [11]. Thus new approaches are urgently needed. Interest on possible use of environment friendly natural products such as extracts of plants or plant parts increased for vector control. Plant derived products have received increased attention from scientists and more than 2000 plant species are already known to have insecticide properties [12]. Algae synthesize a number of chemically diversified secondary metabolites. Among them, some of the compounds are recognized as insecticides. The control of adult mosquito is an unsuccessful strategy, as the adult stage occurs beside human inhabitation and they can easily overcome remedial measures [13].

The larvicidal activity of different solvents viz., hexane, chloroform, ethyl acetate, acetone and methanol extracts of $H$. macroloba, $U$. lactuca and $C$. racemosa against $A$. aegypti and the results are presented in (Tables 2-3) which shows that in case of $4^{\text {th }}$ instar of $A$. aegypti $1000 \mathrm{ppm}$ concentration exhibits mortality at 24 and 48 hours (for 200, 400, 600, 800 and 1000 ppm concentration). The larvicidal mortality rate which increase with time of exposure $(24 \mathrm{~h}>48 \mathrm{~h})$. Tables 2-3 reveals significant difference in larvicidal mortality of $\log$ probit analysis at $95 \%$ confidence level where $\mathrm{LC}_{50}$ and $\mathrm{LC}_{90}$ values. The highest activity of ethyl acetate extract of $C$. racemosa against the larva of $A$. aegypti $\left(\mathrm{LC}_{50}=579.9\right.$ and $\mathrm{LC}_{90}=1255.4 \mathrm{ppm}$ values at $24 \mathrm{~h}$ and $\mathrm{LC}_{50}$ and $\mathrm{LC}_{90}$ values of 495.4 and $1073.9 \mathrm{ppm}$ at $48 \mathrm{~h}$ and U. lactuca $\left(\mathrm{LC}_{50}=588.1\right.$ and $\mathrm{LC}_{90}=1290.7 \mathrm{ppm}$ values at $24 \mathrm{~h}$ and $\mathrm{LC}_{50}=530.8$ and $\mathrm{LC}_{90}=1160.0 \mathrm{ppm}$. at $48 \mathrm{~h}$ ), respectively. The lowest larval mortality was observed with hexane extract of $H$. macroloba against A. aegypti with values of $\mathrm{LC}_{50}=1116.8$ and $\mathrm{LC}_{90}=1824.5 \mathrm{ppm}$ (after $24 \mathrm{~h}$ ) and $\mathrm{LC}_{50}=1059.9$ and $\mathrm{LC}_{90} 1768.3$ (after 24 h). Ali et al. [14] reported that the seaweed extracts of U. lactuca, C. racemosa, Sargassum microystum, Caulerpa scalpelliformis, Gracilaria corticata, Turbinaria decurrens, Turbinaria conoides and Caulerpa toxifolia against mosquito larvicidal activity. Among the seaweed extracts, C. racemosa showed toxicity against $4^{\text {th }}$ instar larvae of A. aegypti, Culex quinquefasciatus and Anopheles stephensi with equivalent $\mathrm{LC}_{50}$ values $(0.0556 \pm 0.0103) \mu \mathrm{g} / \mathrm{mL}$, $(0.0675 \pm 0.1360) \mu \mathrm{g} / \mathrm{mL}$ and $(0.0661 \pm 0.0076) \mu \mathrm{g} / \mathrm{mL}$, respectively. Manilal et al. [15] reported that the Lobophora variegate $\left(\mathrm{LD}_{50}=95.5 \mathrm{ppm}\right)$, Spatoglossum asperum $\left(\mathrm{LD}_{50}=96.1 \mathrm{ppm}\right)$ and $S$. marginatum $\left(\mathrm{LD}_{50}=97.3 \mathrm{ppm}\right)$ against third instar larvae of $A$. aegypti. Thangam and Kathiresan[16] reported that the number of other components of algal extracts have been shown to act as larvicidal agents against mosquito vectors. Thus, acetone extracts of the marine seaweeds Caulerpa scapelliformis, D. dichotoma, Enteromorpha clathrata, E. intestinalis and U. lactuca were active against fourth instar larvae of $A$. aegypti with $\mathrm{LC}_{50}$ values of 53.70, 61.65, 85.11, 67.70 and $91.20 \mathrm{ppm}$, respectively.

Padina minor showed significantly greater larvicidal activity compared to $D$. linearis at $\mathrm{LC}_{50}$. Greater larvicidal activity of Padina than Dictyota was also observed in P. tetrastromatica and D. dichotoma from southwest Coast of India [17]

Table 2. Mortality effects of 24 hours A. aegypti exposed to different concentration of crude extracts of selected Marine macro algae.

\begin{tabular}{|c|l|c|c|c|c|c|}
\hline \multirow{4}{*}{ Seaweeds } & $\begin{array}{c}\text { Seaweeds } \\
\text { prepared with } \\
\text { different } \\
\text { solvents }\end{array}$ & \multicolumn{4}{|c|}{ \% Mortality \pm SD } & \multicolumn{2}{c|}{ (Concentration of ppm) } \\
\cline { 3 - 7 } & & 200 & 400 & 600 & 800 & 1000 \\
\hline \multirow{4}{*}{$\begin{array}{l}\text { Halimeda } \\
\text { macroloba }\end{array}$} & Hexane & $5.8 \pm 1.48$ & $9.6 \pm 0.54$ & $17.2 \pm 1.09$ & $31.0 \pm 0.70$ & $40.2 \pm 1.09$ \\
\cline { 2 - 7 } & Chloroform & $7.8 \pm 0.83$ & $13.2 \pm 0.44$ & $24.2 \pm 1.09$ & $36.4 \pm 0.57$ & $49.6 \pm 0.54$ \\
\cline { 2 - 7 } & Ethyl acetate & $11.0 \pm 1.22$ & $19.4 \pm 1.64$ & $34.6 \pm 0.83$ & $46.0 \pm 0.89$ & $54.2 \pm 1.09$ \\
\cline { 2 - 7 } & Acetone & $6.4 \pm 0.57$ & $11.6 \pm 0.54$ & $20.8 \pm 1.48$ & $32.1 \pm 0.48$ & $42.6 \pm 0.54$ \\
\cline { 2 - 7 } & Methanol & $5.2 \pm 1.09$ & $9.2 \pm 1.78$ & $17.4 \pm 0.57$ & $32.8 \pm 1.48$ & $41.2 \pm 1.09$ \\
\hline
\end{tabular}




\begin{tabular}{|l|l|c|c|c|c|c|}
\hline \multirow{4}{*}{$\begin{array}{c}\text { Caulerpa } \\
\text { racemosa }\end{array}$} & Hexane & $15.2 \pm 0.63$ & $25.4 \pm 1.64$ & $33.8 \pm 1.09$ & $42.0 \pm 0.70$ & $56.6 \pm 0.89$ \\
\cline { 2 - 7 } & Chloroform & $18.2 \pm 0.83$ & $35.2 \pm 0.83$ & $44.6 \pm 0.89$ & $53.2 \pm 1.09$ & $65.3 \pm 1.44$ \\
\cline { 2 - 7 } & Ethyl acetate & $21.4 \pm 1.14$ & $37.0 \pm 0.70$ & $56.2 \pm 0.83$ & $67.4 \pm 0.54$ & $76.6 \pm 0.89$ \\
\cline { 2 - 7 } & Acetone & $16.2 \pm 0.09$ & $30.4 \pm 0.59$ & $36.0 \pm 0.70$ & $48.2 \pm 0.83$ & $62.6 \pm 0.89$ \\
\cline { 2 - 7 } & Methanol & $13.8 \pm 1.09$ & $22.0 \pm 1.22$ & $35.6 \pm 0.59$ & $46.0 \pm 0.70$ & $52.2 \pm 1.30$ \\
\hline \multirow{4}{*}{\begin{tabular}{l} 
Ulva actuca \\
\cline { 2 - 7 }
\end{tabular}} & Hexane & $13.0 \pm 0.70$ & $22.7 \pm 1.09$ & $30.6 \pm 1.14$ & $41.2 \pm 1.22$ & $53.0 \pm 0.70$ \\
\cline { 2 - 7 } & Chloroform & $17.1 \pm 1.0$ & $33.2 \pm 1.48$ & $41.6 \pm 1.14$ & $52.0 \pm 0.70$ & $63.2 \pm 1.09$ \\
\cline { 2 - 7 } & Ethyl acetate & $19.4 \pm 1.14$ & $36.8 \pm 0.44$ & $55.1 \pm 1.0$ & $69.6 \pm 0.89$ & $73.6 \pm 1.14$ \\
\cline { 2 - 7 } & Acetone & $16.2 \pm 1.48$ & $28.0 \pm 0.70$ & $34.7 \pm 1.09$ & $49.2 \pm 1.22$ & $60.2 \pm 0.83$ \\
\cline { 2 - 7 } & Methanol & $12.6 \pm 0.54$ & $21.0 \pm 1.22$ & $34.2 \pm 0.83$ & $41.6 \pm 0.54$ & $51.4 \pm 059$ \\
\hline
\end{tabular}

Control- Nil activity; SD - Standard Deviation; ${ }^{\text {a }}$ Values are Mean \pm SD of five replicates; ${ }^{b}$ Each of the dilutions made with the solvent DMSO

Table 2a. $\mathrm{LC}_{50}, \mathrm{LC}_{90}$ and other statistically analysis of selected marine macro algae extracts fourth instars larvae of $A$. aegypti.

\begin{tabular}{|c|c|c|c|c|}
\hline Seaweeds & $\begin{array}{l}\text { Seaweeds prepared } \\
\text { with different } \\
\text { solvents }\end{array}$ & $\mathbf{L C}_{50}(\mathrm{LCL}-\mathrm{UCL})^{\mathrm{a}}$ & $\mathbf{L C}_{90}(\mathrm{LCL}-\mathrm{UCL})^{\mathrm{a}}$ & $\chi^{2}(d f=4)^{\mathrm{b}}$ \\
\hline \multirow{5}{*}{$\begin{array}{l}\text { Halimeda } \\
\text { macroloba }\end{array}$} & Hexane & $1116.8(1004.1-1300.2)$ & $1824.5(1570.4-2268.0)$ & 0.599 \\
\hline & Chloroform & $1003.7(911.8-1142.6)$ & $1706.1(1485.8-2073.9)$ & 0.108 \\
\hline & Ethyl acetate & $894.9(812.5-1013.0)$ & $1653.9(1437.1-2016.5)$ & 1.233 \\
\hline & Acetone & $1109.9(992.6-1304.1)$ & $1869.4(1596.1-2356.2)$ & 0.347 \\
\hline & Methanol & $1119.0(1003.3-1292.8)$ & $1890.3(1561.2-2239.2)$ & 0.343 \\
\hline \multirow{5}{*}{ Ulva lactuca } & Hexane & $950.3(849.4-1109.4)$ & $1823.0(1545.6-2323.7)$ & 0.99 \\
\hline & Chloroform & $761.6(683.7-862.6)$ & $1611.7(1386.9-2000.9)$ & 1.247 \\
\hline & Ethyl acetate & $588.1(526.3-662.8)$ & $1298.7(1042.6-1487.9)$ & 1.361 \\
\hline & Acetone & $831.0(748.1947 .3)$ & $1673.6(1437.2-2083.8)$ & 0.68 \\
\hline & Methanol & 952.9 (890.9-1113.7) & $1830.4(1549.9-2339.6)$ & 0.977 \\
\hline \multirow{5}{*}{$\begin{array}{l}\text { Caulerpa } \\
\text { racemosa }\end{array}$} & Hexane & $910.2(812.3-1062.1)$ & $1813.7(1532.9-2326.3)$ & 0.33 \\
\hline & Chloroform & $728.4(652.0-823.0)$ & $1579.2(1360.8-1955.7)$ & 1.599 \\
\hline & Ethyl acetate & $579.9(516.3-641.6)$ & $1255.4(1123.1-1456.9)$ & 1.645 \\
\hline & Acetone & $811.8(730.8-923.1)$ & $1643.0(1421.2-2054.0)$ & 0.955 \\
\hline & Methanol & $886.0(791.5-1029.8)$ & $1790.1(1514.9-2290.8)$ & 0.600 \\
\hline
\end{tabular}

LCL lower confidence level, UCL upper confidence level a $95 \%$ Confidence interval

$\mathrm{b}$ Degrees of freedom; $\chi^{2}=$ Chi-square value

Table 3. Mortality effects of 48 hours A. aegypti exposed to different concentration of crude extracts of selected Marine macro algae.

\begin{tabular}{|c|c|c|c|c|c|c|}
\hline \multirow{2}{*}{ Seaweeds } & \multirow{2}{*}{$\begin{array}{c}\text { Solvents } \backslash \\
\text { Extracts }\end{array}$} & \multicolumn{2}{|c|}{$\%$ Mortality \pm SD } & \multicolumn{3}{|c|}{ (Concentration of ppm) } \\
\hline & & 200 & 400 & 600 & 800 & 1000 \\
\hline \multirow{5}{*}{$\begin{array}{l}\text { Halimeda } \\
\text { macroloba }\end{array}$} & Hexane & $8.6 \pm 0.54$ & $14.8 \pm 1.48$ & $27.8 \pm 0.48$ & $32.0 \pm 0.70$ & $46.2 \pm 0.44$ \\
\hline & Chloroform & $9.4 \pm 0.54$ & $17.0 \pm 1.0$ & $31.4 \pm 0.57$ & $40.6 \pm 0.54$ & $52.8 \pm 1.98$ \\
\hline & Ethyl acetate & $14.2 \pm 0.83$ & $26.0 \pm 1.22$ & $43.8 \pm 0.83$ & $51.6 \pm 0.89$ & $60.6 \pm 1.14$ \\
\hline & Acetone & $9.2 \pm 0.49$ & $17.0 \pm 1.0$ & $28.8 \pm 1.98$ & $36.8 \pm 0.48$ & $46.6 \pm 1.0$ \\
\hline & Methanol & $8.2 \pm 0.83$ & $13.2 \pm 1.09$ & $24.6 \pm 1.93$ & $33.0 \pm 1.0$ & $45.6 \pm 0.89$ \\
\hline \multirow{3}{*}{$\begin{array}{l}\text { Caulerpa } \\
\text { racemosa }\end{array}$} & Hexane & $16.6 \pm 0.89$ & $27.0 \pm 0.70$ & $33.6 \pm 1.14$ & $44.8 \pm 1.08$ & $62.2 \pm 0.83$ \\
\hline & Chloroform & $20.6 \pm 0.89$ & $35.8 \pm 0.83$ & $47.0 \pm 1.0$ & $60.2 \pm 0.83$ & $71.0 \pm 1.22$ \\
\hline & Ethyl acetate & $26.2 \pm 1.30$ & $43.8 \pm 1.09$ & $59.6 \pm 0.89$ & $70.4 \pm 1.64$ & $90.0 \pm 1.22$ \\
\hline
\end{tabular}




\begin{tabular}{|c|c|c|c|c|c|c|}
\hline & Acetone & $18.8 \pm 1.09$ & $33.1 \pm 1.14$ & $43.0 \pm 1.22$ & $55.2 \pm 0.83$ & $66.6 \pm 0.89$ \\
\cline { 2 - 7 } & Methanol & $15.2 \pm 1.30$ & $25.6 \pm 0.89$ & $37.8 \pm 1.09$ & $45.6 \pm 0.59$ & $55.0 \pm 0.70$ \\
\hline \multirow{4}{*}{ Ulva lactuca } & Hexane & $15.2 \pm 0.83$ & $26.0 \pm 0.70$ & $33.2 \pm 1.09$ & $42.0 \pm 0.70$ & $55.8 \pm 0.83$ \\
\cline { 2 - 7 } & Chloroform & $19.2 \pm 1.48$ & $35.6 \pm 0.89$ & $47.0 \pm 0.70$ & $61.6 \pm 0.89$ & $70.4 \pm 0.54$ \\
\cline { 2 - 7 } & Ethyl acetate & $24.8 \pm 0.83$ & $41.0 \pm 0.70$ & $57.6 \pm 0.89$ & $68.6 \pm 1.14$ & $84.2 \pm 1.22$ \\
\cline { 2 - 7 } & Acetone & $17.1 \pm 1.0$ & $30.2 \pm 1.48$ & $41.6 \pm 0.89$ & $52.6 \pm 1.14$ & $63.6 \pm 0.89$ \\
\cline { 2 - 7 } & Methanol & $14.0 \pm 0.70$ & $23.8 \pm 0.83$ & $34.6 \pm 0.89$ & $43.2 \pm 1.09$ & $54.4 \pm 0.89$ \\
\hline
\end{tabular}

Control- Nil activity; SD - Standard Deviation; ${ }^{a}$ Values are Mean \pm SD of five replicates; ${ }^{b}$ Each of the dilutions made with the solvent DMSO

Table 3a. $\mathrm{LC}_{50}, \mathrm{LC}_{90}$ and other statistically analysis of selected marine macro algae extracts fourth instars larvae of $A$. aegypti.

\begin{tabular}{|c|c|c|c|c|}
\hline $\begin{array}{c}\text { Seaweeds } \\
\text { name }\end{array}$ & Solvents $\backslash$ Extracts & $\mathbf{L C}_{50}(\mathrm{LCL}-\mathrm{UCL})^{\mathrm{a}}$ & $\mathbf{L C}_{90}(\mathrm{LCL}-\mathrm{UCL})^{\mathrm{a}}$ & $\chi^{2}(d f=4)^{b}$ \\
\hline \multirow{5}{*}{$\begin{array}{l}\text { Halimeda } \\
\text { macroloba }\end{array}$} & Hexane & $1059.9(946.8-1245.7)$ & $1768.3(1868.3-1588.9)$ & 1.050 \\
\hline & Chloroform & $947.4(859.0-1079.0)$ & $1697.9(1472.1-208.4)$ & 0.810 \\
\hline & Ethyl acetate & 794.0 (719.4-892.2) & $1578.5(1373.0-1921.3)$ & 2.197 \\
\hline & Acetone & $1040.9(926.6-1230.6)$ & $1893.9(1600.3-2430.6)$ & 0.650 \\
\hline & Methanol & $1070.1(956.8-1256.0)$ & $1863.9(1588.1-2355.8)$ & 0.237 \\
\hline \multirow{5}{*}{$\begin{array}{l}\text { Ulva } \\
\text { lactuca }\end{array}$} & Hexane & $919.1(817.2-1080.9)$ & $1853.0(1556.3-2405.6)$ & 0.479 \\
\hline & Chloroform & $651.8(583.2-726.0)$ & $1416.2(1244.0-1695.2)$ & 0.471 \\
\hline & Ethyl acetate & $530.8(468.3-588.2)$ & $1160.6(1046.7-1329.1)$ & 0.681 \\
\hline & Acetone & $768.1(692.0-866.6)$ & $1590.6(1375.5-1956.3)$ & 0.480 \\
\hline & Methanol & $917.2(820.1-1067.3)$ & $1801.7(1527.4-2297.4)$ & 0.235 \\
\hline \multirow{5}{*}{$\begin{array}{l}\text { Caulerpa } \\
\text { racemosa }\end{array}$} & Hexane & $837.5(754.2-955.2)$ & $1676.9(1440.3-22087.3)$ & 0.947 \\
\hline & Chloroform & $656.4(588.9-7298)$ & $1407.9(1239.4-1678.6)$ & 0.951 \\
\hline & Ethyl acetate & $495.4(435.3-549.1)$ & $1073.9(976.4-1213.9)$ & 2.308 \\
\hline & Acetone & $722.5(650.1-810.1)$ & $1526.2(1327.2-1858.9)$ & 0.718 \\
\hline & Methanol & $886.0(791.5-1029.8)$ & $1790.1(1574.9-2290.8)$ & 0.600 \\
\hline
\end{tabular}

LCL - lower confidence level, UCL - upper confidence level

${ }^{\text {a }} 95 \%$ Confidence interval

${ }^{\mathrm{b}}$ Degrees of freedom; $\chi^{2}=$ Chi-square value

In the present study the highest activity of ethyl acetate extract of $C$. racemosa against the larva of $A$. aegypti $\left(\mathrm{LC}_{50}=579.9\right.$ and $\mathrm{LC}_{90}=1255.4 \mathrm{ppm}$ values at $24 \mathrm{~h}$ and $\mathrm{LC}_{50}$ and $\mathrm{LC}_{90}$ values of 495.4 and $1073.9 \mathrm{ppm}$ at $48 \mathrm{~h}$ and $U$. lactuca $\left(\mathrm{LC}_{50}=588.1\right.$ and $\mathrm{LC}_{90}=1290.7 \mathrm{ppm}$ values at $24 \mathrm{~h}$ and $\mathrm{LC}_{50}=530.8$ and $\mathrm{LC}_{90}=1160.0 \mathrm{ppm}$. at $48 \mathrm{~h}$ ), respectively. Adaikala Raj et al. [18] revealed that the essential oil from Nigella sativa was evaluated against the fourth instar larvae of $A$. aegypti, A. stephensi and C. quinquefasciatus. After $12 \mathrm{~h}$ of exposure period, the larvicidal activities were $\mathrm{LC}_{50}=196.9$ and $\mathrm{LC}_{90}=523.5 \mathrm{ppm}\left(\right.$ A aegypti), $\mathrm{LC}_{50}=88.1$ and $\mathrm{LC}_{90}=272.4 \mathrm{ppm}$ (A. stephensi), and $\mathrm{LC}_{50}=241.6$ and $\mathrm{LC} 90=545.4 \mathrm{ppm}$ ( $C$. quinquefasciatus), and the larvicidal activities after $24 \mathrm{~h}$ of exposure period were $\mathrm{LC}_{50}=99.9$ and $\mathrm{LC}_{90}=300.8 \mathrm{ppm}\left(A\right.$. aegypti), $\mathrm{LC}_{50}=53.9$ and $\mathrm{LC}_{90}=172.6 \mathrm{ppm}$ (A. stephensi) and $\mathrm{LC}_{50}=141.7$ and $\mathrm{LC}_{90}=364.0 \mathrm{ppm}$ (C. quinquefasciatus). The leaf essential oil from Murraya exotica had a strong larvicidal activity with $\mathrm{LC}_{50}=74.7$ and $\mathrm{LC}_{90}=152.7$ (after $12 \mathrm{~h}$ ); $\mathrm{LC}_{50}=35.8$ and $\mathrm{LC}_{90}=85.4 \mathrm{ppm}$ (after $24 \mathrm{~h}$ ) against $A$. aegypti, $\mathrm{LC}_{50}=56.3$ and $\mathrm{LC}_{90}=107.8$ (after $12 \mathrm{~h}$ ); $\mathrm{LC}_{50}=31.3$ and $\mathrm{LC}_{90}=75.1 \mathrm{ppm}$ (after $24 \mathrm{~h}$ ) against A. stephensi and $\mathrm{LC}_{50}=74.4$ and $\mathrm{LC}_{90}=136.9 \mathrm{ppm}$ (after $12 \mathrm{~h}$ ); $\mathrm{LC}_{50}=43.2$ and $\mathrm{LC}_{90}=103.2 \mathrm{ppm}$ (after $24 \mathrm{~h}$ ) against C. quinquefasciatus [19].

In this study, the ethyl acetate extract of $C$. racemosa green alga the highest larvicidal activity may be due to the presence of phytochemicals, terpenoids, tannins and phenolic compounds. Many 
of the secondary metabolites produced by plants for its protection against microorganisms and predator insects are natural source for the discovery of new plants based products to combat A. aegypti. Many researchers have been focused on natural products for controlling Aedes mosquito as insecticide and larvicide with varied results [20]. The biological activities of this marine plant extracts might be due to various compounds, including phenolics, terpenoids, flavonoids, saponins and alkaloids existing in plant. These compounds may jointly or independently contribute to produce larvicidal activity against mosquitoes [17].

\section{Conclusion}

The results of the present study suggest the larvicidal activity of hexane, chloroform, ethyl actate, acetone and methanol extracts of $H$. macroloba, C. racemosa and U. lactuca against $A$. aegypti. Among the ethyl acetate crude extract of $C$. racemosa could be used for mosquito control. The C. racemosa ethyl acetate extract can be well utilized for preparing biocide or insecticide formulation, effects on non-target organisms and field evaluation are necessary. In that way, the results of the present study offer a possible way for further investigations to find out the active molecule needed to elucidate this activity against a wide range of all stages of mosquito species.

\section{Acknowledgement}

The authors acknowledge gratefully the financial support sanctioned by the University Grants Commission, New Delhi under Major Research Project Programme (F. No.: 40-312/2011(SR) Dated: 30.06.2011). The authors are thankful to Dr. K. Arumugam, Professor and Head, Department of Botany, Annamalai University for providing laboratory facilities.

\section{References}

[1] P. Bhadury, C.P. Wright, Exploitation of marine algae: biogenic compounds for potential antifouling application, In Planta. 219 (2004) 561-578.

[2] V. Dhargalkar, K. Neelam Pereira, Seaweed: Promising plant of the Millennium. Sci. Cul. 71 (2005) 60-66.

[3] E. Sandsdalen et al., The antibacterial effect of a polyhydroxylated fucophlorethol from the marine brown alga, Fucus vesiculosus, World. J. Microbiol. Biotechnol. 19 (2003) 777-782.

[4] World Health Organization, A global brief on vector-borne diseases. WHO/DCO/WHD/2014; 1 .

[5] L. Roberts, Mosquitoes and disease, Sci. 298 (2002) 82-83.

[6] World Health Organization, Dengue and dengue haemorrhagic fever. Fact sheet 2002; 117.

[7] K. Samidurai et al., Larvicidal, ovicidal and repellent activities of Pemphis acidula forst (Lythraceae) against filarial and dengue vector mosquitoes, Acada. J. Entomol. 2(2) (2009) 62-66.

[8] A. Manilal et al., Biopotentials of seaweeds collected from southwest coast of India, J. Mar. Sci. Technol. 17 (2009) 67-73.

[9] I.B. Harborne, Phytochemical methods: A guide to modern techniques of plant analysis, 2nd ed., Chapman and Hall, New York, 1973, pp. 88-185.

[10] World Health Organization. Instruction for determining the susceptibility or resistance of mosquito larvae to insecticides. WHO-VBC 81.807 (1981) 1-6.

[11] M. Govindarajan, A. Jebanesan, T. Pushpanathan, Larvicidal and ovicidal activity of Cassia fistula Linn. leaf extract against filarial and malarial vector mosquitoes, Parasitol. Res. 102 (2008) 289-292. 
[12] M.P. Isman, Pesticides based on plant essential oils for management of plant pests and disease. In: International Symposium on Development of Natural Pesticides from Forest Resources. Seoul: Korea Forest Research Institute, 2001, pp. 1-9.

[13] M.W. Service, Mosquitoes (Culicidae), in: R.P. Lane, R.W. Crosskey (Eds.), Medical insects and arachnids. Chapman and Hall, London, 1993, pp. 723-725.

[14] M.Y.S. Ali, S. Ravikumar, J.M. Beula, Mosquito larvicidal activity of seaweeds extracts against Anopheles stephensi, Aedes aegypti and Culex quinquefasciatus, Asian Pac. J. Trop. Dis. 3 (2013) 196-201.

[15] A. Manilal et al., Biological activity of the red alga Laurencia brandenii, Acta Bot. Croat. 70 (2011) 81-90.

[16] T.S. Thangam, K. Kathiresan, Mosquito larvicidal effect of seaweed extracts, Bot. Mar. 34 (1991) 433-5.

[17] S. Ravikumar et al., Antiplasmodial activity of two marine polyherbal preparations from Chaetomorpha antennina and Aegiceras corniculatum against Plasmodium falciparum, Parasitol. Res. 108 (2010) 107-13.

[18] G. Adaikalaraj et al., Phytochemical profile and larvicidal properties of seed essential oil from Nigella sativa L. (Ranunculaceae), against Aedes aegypti, Anopheles stephensi and Culex quinquefasciatus (Diptera: Culicidae), Parasitol Res. 114 (2015) 3385-3391.

[19] S. Krishnamoorthy, G. Adaikala Raj, M. Chandrasekaran, Antibacterial and antifungal activity of leaves of Thespesia populnea, Int. J. Pharm. Pharmace. Sci. 6(8) (2014) 404-411.

[20] C.E. Chariandy et al., Screenig of medicinal plants from Trinidad and Tobago for antimicrobial and insecticidal properties, J. Ethnopharmacol. 64 (1999) 265-270. 